University of Warwick institutional repository: http://go.warwick.ac.uk/wrap This paper is made available online in accordance with publisher policies. Please scroll down to view the document itself. Please refer to the repository record for this item and our policy information available from the repository home page for further information.

To see the final version of this paper please visit the publisher's website. Access to the published version may require a subscription.

Author(s): Nadje Al-Ali and Nicola Pratt Article Title: Women in Iraq: Beyond the Rhetoric Year of publication: 2006

Link to published version: http://www.acttogether.org/MERIP06.htm

Publisher statement: The definitive version is available at www.blackwell-synergy.com 
Middle East Report no. 239, summer 2006, pp. 18-23.

\title{
Women in Iraq: Beyond the Rhetoric
}

\author{
Nadje Al-Ali and Nicola Pratt
}

AUTHOR ID: Nadje Al-Ali is senior lecturer in social anthropology at the Institute of Arab and Islamic Studies, University of Exeter. Nicola Pratt is lecturer in comparative politics and international relations at the University of East Anglia. This article is based on interviews conducted in Jordan, the US and Great Britain with Iraqi women activists, government policymakers and people working in bilateral and multinational development agencies and international NGOs. This work is supported by a grant from the British Academy.

At a press conference two weeks before the US-led invasion of Iraq, flanked by four "Women for a Free Iraq,"1 Paula Dobriansky, then undersecretary of state for global affairs, declared: "We are at a critical point in dealing with Saddam Hussein. However this turns out, it is clear that the women of Iraq have a critical role to play in the future revival of their society." For the Bush administration, Iraqi women would not only be "helping give birth to freedom" in the post-Saddam order. ${ }^{2}$ US officials spoke publicly about rape, torture and executions of women under Ba'th Party rule, implicitly linking these atrocities to the necessity for US military action. ${ }^{3}$

These proclamations of support, however, have not necessarily resulted in the greater empowerment of Iraqi women. Rather, as symbols of the post-Saddam political order, women have become instruments for achieving (US-defined) security ends. The Bush administration assumed that Iraqi women constituted a monolithic bloc, who would unanimously welcome US "liberation" and represent a natural constituency for the Coalition Provisional Authority’s policies, irrespective of war's cost to them and their families. Meanwhile, various political groupings inside Iraq have also appropriated the experiences of women of "their" communities to further their own agendas. Caught between the objectives of the US occupation and those of the competing Iraqi factions, women are finding it increasingly difficult to articulate an independent voice.

\section{Women's Gains in Post-Saddam Iraq}

The Bush administration would vehemently deny that its interest in empowering Iraqi women exists only at the level of official rhetoric. In the early days of the occupation, the Coalition Provisional Authority (CPA) established an Office of Women's Affairs, which acted as a "clearinghouse," matching Iraqi civil society groups with donors. The office also provided technical support for one national and several regional conferences for women. In addition, there were weekly meetings between the Office of Women's Affairs, Iraqi women's groups, government agencies and anyone else

\footnotetext{
${ }^{1}$ Women for a Free Iraq is a group of Iraqi women living in exile, formed in January 2003 to raise awareness of women's experience of persecution under Saddam Hussein. The campaign received funding from the Washington-based Foundation for the Defense of Democracies. Though the foundation is nominally non-partisan, its president, Clifford May, is a former Republican Party operative and its board is stacked with prominent neo-conservatives.

2 Paul Wolfowitz, "Women in the New Iraq," Washington Post, February 1, 2004.

${ }^{3}$ See, for example, the State Department's Office of International Women's Issues fact sheet distributed on March 20, 2003, accessible online at http://www.state.gov/g/wi/rls/18877.htm.
} 
who was interested in promoting women's interests. CPA head L. Paul Bremer himself met with Iraqi women activists on several occasions. As one international NGO worker observed, “The Iraqi women's organizations got themselves organized much faster than anyone else so they were constantly in appearance, meeting with senior officials and pushing for more change.”

The State Department seeks to demonstrate the ongoing "US Commitment to Women in Iraq" with semi-regular fact sheets produced by the Office of the Senior Coordinator for International Women's Issues. These releases report expenditures of US reconstruction funds to involve more women in formal politics and civil society, and to improve women's economic and social situation. ${ }^{4}$ As a result, women have been "educated" as voters, and trained as parliamentary candidates and members of local councils, while women's groups have been funded as a means of strengthening civil society. In addition, \$10 million in reconstruction money was ring-fenced for Iraqi women through an Iraqi Women's Democracy Initiative. The grants were disbursed quickly in order to "bring women into the political process immediately," according to one State Department person involved.

Within the upsurge of civil society activism following the fall of the repressive Ba'th regime, many women became active in claiming their rights to participate in the rebuilding of their country. Several women's conferences were held around the country, at which there was a consensus, irrespective of the "secular-religious" divide, that women should hold at least 30 percent of all elected offices. In the words of activist Safiyya al-Suhail, this was "the only way to force [male politicians] to have a number of skillful women [in leadership positions] ${ }^{5}$ Women also demonstrated on the streets of Baghdad, demanding quotas for women in elected assemblies. ${ }^{6}$ While the Bush administration can claim that their support for Iraqi women helped to stimulate this organizing to defend women's interests, their record with regard to institutionalizing women's participation within governance structures is not easy to defend.

The Bush administration refused to support quotas for women-despite establishing de facto quotas for different communal groups on the Iraqi Governing Council (IGC), a consultative body of limited authority created in July 2003. Indeed, Bremer appointed only three women to the IGC — a move regarded by many as tokenistic. Despite Bremer's opposition, Iraqi women activists achieved the compromise of a 25 percent target for women's participation in elected assemblies in the Transitional Administrative Law and the permanent constitution. As a result, women won over 30 percent of parliamentary seats in the January elections - but only 19 percent in the December 2005 elections (the 25 percent target will be met by allocating compensatory seats to women). ${ }^{7}$ Although there is no gender-disaggregated data for voting, women were certainly among those who braved threats of violence to cast their ballots. In addition to reaching elected positions to the National Assembly, women hold positions in municipal and local councils, the Iraqi Electoral Commission, as well as various government cabinets, including the newly created portfolio of State Minister for Women's Affairs. Although women remain

\footnotetext{
${ }^{4}$ The most recent fact sheet was released on June 22, 2005, and is accessible online at http://www.state.gov/g/wi/rls/48464.htm.

${ }^{5}$ Christian Science Monitor, December 17, 2003.

${ }_{6}^{6}$ Knight Ridder, February 21, 2004.

${ }^{7}$ Zainab Naji, “Female Politicians Fear Exclusion,” Institute for War and Peace Reporting Iraq Crisis Report 174, April 26, 2006.
} 
underrepresented in positions of decision-making, their achievements demonstrate women's perseverance to participate in the rebuilding of Iraq.

Iraqi women's perseverance was also crucial in helping to stop the passage of Resolution 137 in early 2004. The proposed law, suggested at the end of 2003 by members of the IGC when that body was under the rotating chairmanship of 'Abd al'Aziz al-Hakim, a leader of the Supreme Council for the Islamic Revolution in Iraq (SCIRI), could have replaced Iraq's unified personal status code with laws rooted in more conservative interpretations of shari ‘a (Islamic jurisprudence). ${ }^{8}$ Many women’s activists (though by no means all) vehemently opposed Resolution 137 as a retrograde step for women's position in Iraq. ${ }^{9}$ Hundreds of Iraqi women demonstrated on the streets and lobbied the ICG, the CPA and international bodies to prevent the proposal from passing into law. Following several weeks of protests, Bremer did not ratify the resolution, thereby rendering it a dead letter. Many supporters of women's rights criticize Bremer for taking so long to cancel the proposal. Women's activists recognize, however, that Resolution 137 was significant in forming new transnational networks of solidarity for women's rights in Iraq.

\section{Iraqi Women in the Diaspora}

Since 2003, Iraqi diaspora women have been actively involved in debates about the political future of Iraq, the role of the US and women's place in the national fabric. The centrality of the US in Iraq's political development, including the building of political institutions, the drafting of the constitution and the allocation of resources, places Iraqi women activists in the US in a crucial position. Just like their male counterparts, Iraqi women activists represent a range of views resonating with the diversity of political positions inside Iraq. Many US-based Iraqi women activists and organizations have helped to shape emerging women's organizations and groups inside Iraq. However, pro-war and pro-occupation Iraqi women's associations in the US have been given the political space and economic means to portray themselves as representing all Iraqi women and their views. Similar to an array of politicians, international organizations and NGOs, some Iraqi women's organizations in the diaspora tend to claim to speak for Iraqi women, strengthened by their claims of authenticity due to their origins and credibility due to their suffering under the previous regime.

Many Iraqi women activists in the US have been working closely with the US government. Women for a Free Iraq, which then formed the Women's Alliance for a Democratic Iraq, represented an important support for US war efforts, and subsequently received US grants to build organizations on the ground. Women activists working through the Kurdistan Democratic Party, the Patriotic Union of Kurdistan and the Shi'i Da'wa Party also welcomed the invasion. Islamist women supporters of Da'wa, however, expressed suspicions of US intentions and have largely stayed independent from government-led activities, especially where women are concerned. In the words of Zaynab K., a Da'wa and community activist in in Dearborn, Michigan: "They betrayed us in 1991 when they asked us to rise up against Saddam and then let his soldiers and tanks slaughter us. Of course, I am happy that they got rid of Saddam, but I don't trust them. Their policies on women are part of their project on imposing their culture on everyone else.”

\footnotetext{
${ }^{8}$ For more details, see Noga Efrati, "Negotiating Rights in Iraq: Women and the Personal Status Law," Middle East Journal 59/4 (Autumn 2005).

${ }^{9}$ Agence France Presse, January 13, 2004 and Washington Post, January 15, 2005.
} 
In Britain, women's groups and activists represent a greater range of political and ideological orientations, in terms of attitudes toward the war, the occupation and ongoing political developments inside Iraq. Women's groups affiliated to political parties exist side by side with more autonomous women's groups, such as the Organization for Women's Freedom in Iraq, the Iraqi Women's League, Iraqi Women for Peace and Democracy, and Act Together: Women's Action on Iraq.

Political and ideological differences are not easily attributable to specific variables, such as ethnic and religious background. Previous political and personal experiences of Saddam Hussein's regime, education, actual experiences of war and conflict, socialization and current political milieu, as well as personality, are all part of women's political trajectories. Alliances and links with women's or anti-war organizations in the country of residence might also shape the specific attitudes towards politics in Iraq.

Immediately following the invasion, diaspora activists were enthusiastic, but by 2005 many women had become disillusioned. Najwa R., a middle-aged professional woman who has been living in exile for over 30 years, first in London and then Amman in order to be closer to Baghdad, said: "Many Iraqis who lived outside wanted to come inside to help rebuild the country, but we faced this hatred, this anger: 'You did not see it! You did not live it! Why should you come now?' They are very bitter about it. I even felt it with my own family.” Najwa, like many other women, decided to give up because her efforts were not appreciated by people inside Iraq and because everything had gone from bad to worse. In turn, several women echoed the sentiments of Baghdad-based pharmacist and NGO founder Hala F., who complained: "All these women who lived outside for 40 years [and are now coming back to Iraq] want to tell us what we should do.” Many, although, one has to stress, not all, diaspora women are perceived to be patronizing and detached from realities on the ground.

In comparing the political mobilization of diaspora women in Britain and the US, one crucial factor mentioned several times by women is the difficulty of mobilizing when geographically scattered as Iraqi refugees are in the US. While it is certainly the case that it is much easier for Britain-based Iraqi women activists to meet in person-mostly in London — geographical dispersion did not explain the lack of a broad range of women's activism in places like “Arab Detroit," with their large concentrations of Iraqi Chaldeans and Iraqi Shi 'is.

While ethnic and religious divisions exist in both the US and Britain, the large presence of secular political parties in Britain, such as the Iraqi Communist Party and Iraqi National Accord, have contributed to the building of more non-sectarian alliances and organizations. Moreover, the specific political climate in the US, particularly post-September 11, has limited the political spaces and resources available for those not in agreement with US Middle East policy. Several Iraqi women interviewed in the US mentioned their fear of expressing dissent from US policy, even more so following the stringent Patriot Act of 2001. In particular, those women who are not yet US citizens confided that they would not want to jeopardize their chances of obtaining citizenship or risk prolonging the process.

\section{Women Losing Ground}

Over three years after the invasion, there are many signs that Iraqi women might prove to be the biggest losers in post-Saddam Iraq. Iraqi women are struggling more than ever in their day-to-day lives, trying to keep their households going, feed their families and keep everyone alive. Intisar K., who works as a doctor in a hospital in 
Baghdad, spoke for many when she said: "We only have electricity for three to a maximum of five hours a day. There is not enough clean drinking water. Lack of sanitation is a big problem and continues to be one of the main causes of malnutrition, dysentery and death amongst young children." Women themselves are suffering from inadequate health care, an ongoing economic crisis and a lack of basic services provided by the state. The Iraqi infrastructure was already in total disarray after 13 years of the most comprehensive sanctions regime ever imposed on a country. Three years of occupation, increased violence and terrorist attacks, as well as one of the biggest financial corruption scandals in recent history, have prevented any serious reconstruction and only led living conditions to worsen. ${ }^{10}$

Iraqi women suffer particularly acutely from escalating violence and the lack of a properly functioning police force. The insecurity plaguing Iraq has a distinct and debilitating impact on the daily lives of women and girls. Although men make up the majority of the victims of the violence, the climate of fear prevents women from participating in public life. There are reports that girls are missing weeks or even months of school or university as their parents fear for their safety in letting them leave the home. ${ }^{11}$ Similarly, Amnesty International and others report that many women are leaving their jobs.

According to the World Bank, women's labor force participation is low even by Middle East standards. Women's employment has declined not only as a result of insecurity but also because of liberalization of the economy and privatization of stateowned enterprises. Fifty-two percent of employed women hold jobs in public-sector companies, as opposed to a quarter of employed men, ${ }^{12}$ and so women disproportionately face the threat of job loss as those companies are sold off. Plans to downsize the civil service encourage women to take early retirement as a means of avoiding the security risks entailed in going out to work. Women professionals like doctors and academics are targeted, just like their male counterparts, in both kidnappings and non-sectarian assassinations. Those women working for US and other foreign forces, whether as translators, cleaners or laundry personnel, risk their lives and those of their families, as they are considered collaborators by the insurgency.

Iraqi women also suffer from gender-specific threats and violence. Harassment and intimidation on the streets, rape and abduction into sex trafficking are particularly threatening for women whose "sexual honor" is tied up with the honor of whole families and even communities. They have been victims of so-called honor crimes as male relatives seek to rid the family of the shame associated with rape and sexual assault. Women are also assaulted and harassed by Islamist militias that roam the streets of Iraq's cities and increasingly control public spaces, like universities, hospitals and ministries. In the midst of this chaos, there are also numerous gangs of criminals responsible for many of the lootings, kidnappings and sexual assaults. Some gangs specialize in kidnapping girls and trafficking them to Gulf countries. Yet the perpetrators of violence are not all insurgents, militias and criminal gangs. They are also occupying soldiers searching houses, stopping women at checkpoints and interrogating women prisoners.

Conservative Islamist gender ideologies impinge on women's daily lives. Many women in Basra, for example, report that they have been forced to wear

\footnotetext{
${ }^{10}$ See the articles in Third World Quarterly 26/4-5 (June 2005).

${ }^{11}$ Iraqi Legal Development Project, The Status of Women in Iraq (Washington, DC: American Bar Association, 2005), p. 76.

${ }^{12}$ UN Development Program, Iraq Living Conditions Survey 2004 (Baghdad, 2005), p. 116.
} 
headscarves or restrict their movements in fear of harassment from men. Female students from the University of Basra, say that since the war ended, groups of men have begun stopping them at the university gates, shouting at them if their heads were not covered. ${ }^{13}$ These reports and accounts are symptomatic of wider conservative trends and various ways in which women are being used in Iraq-as in many other societies - to demarcate boundaries between "us" and "them." Islamization here fulfils two objectives: a break with the previous secular regime of Saddam Hussein and resistance to the occupying forces. Women are often caught between these two impulses. On the one hand, many women may support the implementation of the shari 'a. 'Azza A., for example, said: "We are Muslims. Of course we want Islamic law." Yet many are also unaware that conservative interpretations of Islamic law could result in restrictions on women's rights to divorce and freedom of movement, increased polygamy or changes to child custody laws.

Islamist political parties and militias in Iraq use women's dress codes, social roles and legal rights to signal a radical break with the deposed regime, which was largely associated with secular politics and even a period of "state feminism" in the 1970s. Conservative Islamist forces are also reacting to the rhetoric of women's rights and liberation coming from the White House and Downing Street by appealing to "cultural authenticity" and "Muslim values." Ironically, the louder political leaders in the West shout "women's rights” while Iraq is occupied, the bigger the backlash against women's rights might be in the long run. Widely circulated images of the female soldier, Pvt. Lynndie England, sexually abusing Iraqi male prisoners at Abu Ghraib, can only worsen this backlash, as Iraqis ask the question: "Is this what women's rights means?”

\section{Gender and the Political Process}

Women's participation is not only threatened by the increasing violence, much of which is sectarian in nature. Sectarianism is itself a barrier not only to the promotion of women's rights but also to the concept of universal citizenship and the political participation of all Iraqis. Where communal identities come to the fore, women's rights and democracy are the losers. Communal political leaders (whether religious, ethnic or tribal) aim to consolidate political power by imposing conformity upon "their" communities, while supporting exclusionary and often discriminatory measures against those who are not perceived as "one of us." The ensuing pressure to follow the leader makes political dissent-and also dissent from socially constructed norms about gender roles and relations_-difficult within the "community." This pressure contributes to social restrictions on women's sexuality and their public roles and behavior.

To a large extent, trends toward sectarianism have been consolidated by postinvasion measures. ${ }^{14}$ It is clear that the Bush administration perceives Iraqi society in terms of a collection of distinct communities: Sunnis, Shi'a, Kurds, Christians, Turkmen and so on. This perception was reflected in the way that the CPA apportioned seats on the IGC, and later ministries in the interim government, according to religious sect and ethnicity. ${ }^{15}$ Subsequently, sectarianism has largely determined political behavior in Iraq. Political parties formed in preparation for the

\footnotetext{
${ }^{13}$ IRINNews.org, "Iraq: Female Harassment from Religious Conservatives,” April 14, 2004.

${ }^{14}$ For a wider discussion, see International Crisis Group, The Next Iraqi War? Sectarianism and Civil Conflict (Amman/Brussels, February 2006).

${ }^{15}$ Raad Alkadiri and Chris Toensing, “The Iraqi Governing Council’s Sectarian Hue,” Middle East Report Online, August 20, 2003.
} 
January 2005 elections vied for power on the basis of sectarian affiliations rather than ideological distinctions. Indeed, those groups that failed to win seats or won only a few seats were those who shunned sectarian politics. This trend was amplified in the December 2005 elections. ${ }^{16}$ In the spring of 2006, political parties representing different communal constituencies fought over positions in government in a way that threatened to establish a de facto confessional system such as exists in Lebanon.

The emergence of sectarian-based politics is also linked to the collapse of the Iraqi state. At the time of the US invasion, Iraqi state institutions were mostly defunct due to the impact of sanctions. ${ }^{17}$ The collapse of the state was hastened by the debaathification policies of Bremer from May 2003, which removed the upper echelons of management from the state apparatus. Yet post-invasion policies have failed to rebuild state institutions. The imposition of timelines for the political process, which has included a series of temporary governments, has greatly hampered capacity building within state institutions and enabled an alarming growth in the violation of human rights, including women's rights, with impunity. ${ }^{18}$

Rather than reconstructing the state, coalition policies have helped to construct a system of patron-client relations that link communally based parties to Iraqi citizens. Members of various temporary cabinets have used their positions to provide goods and services that are in scarce supply through other channels to mobilize a support base. Given the high level of unemployment, one important mechanism of patronclient relations has been access to jobs. ${ }^{19}$ Through the provision of basic goods and services, communally organized parties have mobilized support not only among the unemployed but also among women, who see the benefits of the provision of social services and security by sectarian parties in their communities. ${ }^{20}$

The constitution ratified by national referendum in October 2005 was meant to represent an opportunity for national reconciliation among political factions. Instead, it contributed to increasing sectarian differences-particularly over the issues of federalism, the future of Kirkuk and the role of Islam in public life. Moreover, negotiations over the constitution through the summer of 2005 demonstrated how women's rights have been sacrificed for the sake of political compromise.

While the constitution enshrines women's rights to public participation and, significantly, allows Iraqi women to pass on their nationality to their children, it fails to grant women equal rights within the family. Article 39 states that "Iraqis are free in their adherence to their personal status according to their own religion, sect, belief and choice, and that will be organized by law.” This realises the worst fears of many women's rights activists in that it opens the way for a Lebanese-type system, where family law is governed according to religious sect, thereby legalizing discriminatory practices with regard to marriage, divorce, child custody and inheritance. The system of federalism spelled out in Article 119 devolves authority to the regions to specify family law, thereby allowing regional differences in family law. ${ }^{21}$ The outcome could

\footnotetext{
${ }^{16}$ Patrick Cockburn, “Iraq’s Election Result: A Divided Nation,” The Independent, December 21, 2005.

${ }^{17}$ Toby Dodge, “Iraq’s Future: The Aftermath of Regime Change,” Adelphi Paper 372 (London: International Institute of Strategic Studies, 2005).

${ }^{18}$ UN Assistance Mission for Iraq, Human Rights Report, January 1-February 28, 2006 (Amman, March 2006).

${ }^{19}$ Glen Rangwala, "Democratic Transition and Its Limitations,” in Alex Danchev and John Macmillan, eds. The Iraq War and Democratic Politics (London: Routledge, 2005), pp. 174-175.

${ }^{20}$ Women for Women International, Windows of Opportunity: The Pursuit of Gender Equality in PostWar Iraq (Washington, DC, January 2005), pp. 18-19.

${ }^{21}$ We thank Nathan Brown for pointing out that personal status laws are not designated as among the areas decided by central government. Personal communication, September 2005.
} 
be a more secular-oriented, civil family code in Kurdistan and a religiously inspired, conservative family code in the Shi'i south.

Indeed, certain secular-oriented women activists in the north backed the constitution because of its guarantees for federalism, which, they believe, will ensure that women's rights are respected in the Kurdish region, where the already existing regional government refused Resolution $137 .{ }^{22}$ Meanwhile, women elected on the (largely Shi`i) United Iraqi Alliance list generally support placing family law under the shari ' $a$. For many, shari ' $a$-inspired legislation represents adherence to Iraq’s Islamic identity, in contradistinction to the largely secular-inspired legislation of Saddam's Iraq.

It is significant that family law has become a main arena in which contestation over the future identity of the Iraqi nation-state occurs. Ba'thist measures sought to dismantle the authority of the male heads of family, clan and tribe over women and to replace it with the authority of the state. ${ }^{23}$ The new constitution replaces state authority over women with the authority of communal leaders of the different regions of Iraq - whether Shi'i, Sunni or Kurd. Family law is one of the mechanisms for consolidating a multi-ethnic and multi-religious state on the basis of (religious-ethnic) difference within the private sphere. By devolving family law to the regions, the state accommodates social and religious differences, while encouraging the loyalty of communal leaders to the state. Family law becomes part of a "social contract," trading communal autonomy for women's rights. ${ }^{24}$

\section{Sacrificed, Not Supported}

It is necessary to emphasize that women are not passive victims of the events occurring in post-invasion Iraq. Despite deteriorating security, increasing violence and the failure of reconstruction, many women continue to participate in the rebuilding of their country by forming NGOs, advocating for women's rights and participating in the political process, whether as voters or candidates.

It is not useful to compare women's suffering under the regime of Saddam Hussein with the suffering related to war and occupation. Such an approach disempowers women, who are reduced to symbols of their community and instruments of various political agendas. In contrast, it is important to acknowledge that different women and men experienced the previous regime differently, not only depending on ethnic and religious background, but also depending on social class and political orientation. Despite efforts by international aid agencies and diaspora women activists to support Iraqi women, however, it is necessary to highlight that the space for Iraqi women's empowerment is being eroded by the policies and realities of the US-British occupation and the competition for power among different political actors inside Iraq. In the name of establishing the new Iraq, women's rights are being sacrificed-not supported.

\footnotetext{
${ }^{22}$ Associated Press, February 6, 2004.

${ }^{23}$ Suad Joseph, "Elite Strategies for State Building: Women, Family, Religion and the State in Iraq and Lebanon,” in Deniz Kandiyoti, ed. Women, Islam and the State (Philadelphia: Temple University Press, 1991), pp. 176-200.

${ }^{24}$ Lisa Hajjar makes this argument with regard to Israel and India in her "Religion, State Power and Domestic Violence in Muslim Societies: A Framework for Comparative Analysis,” Law and Social Inquiry 29/1 (Winter 2004).
} 